Volume 16

$$
\text { EIBA }
$$

PROGRESS IN INTERNATIONAL BUSINESSRESEARCH

TRIBUTEVOLUME:

GEOFFREY JONES

\title{
International Business in Times of Crisis
}

\section{EDITED BY}

Rob van Tulder $\bullet$ Alain Verbeke

Lucia Piscitello • Jonas Puck 


\section{INTERNATIONAL BUSINESS IN TIMES OF CRISIS}




\section{PROGRESS IN INTERNATIONAL BUSINESS RESEARCH}

\section{Series Editors: The European International Business Academy (EIBA)}

\section{Recent Volumes:}

Volume 1: Progress in International Business Research - Edited by Gabriel R. G. Benito and Henrich R. Greve

Volume 2: Foreign Direct Investment, Location and Competitiveness - Edited by John H. Dunning and Philippe Gugler

Volume 3: New Perspectives in International Business Research - Edited by Maryann P. Feldman and Grazia D. Santangelo

Volume 4: Research on Knowledge, Innovation and Internationalization Edited by Jorma Larimo and Tia Vissak

Volume 5: Reshaping the Boundaries of the Firm in an Era of Global Interdependence - Edited by José Pla-Barber and Joaquín Alegre

Volume 6: Entrepreneurship in the Global Firm - Edited by Alain Verbeke, Ana Teresa Tavares-Lehmann and Rob van Tulder

Volume 7: New Policy Challenges for European MNEs - Edited by Rob van Tulder, Alain Verbeke and Liviu Voinea

Volume 8: International Business and Sustainable Development- Edited by Rob van Tulder, Alain Verbeke and Roger Strange

Volume 9: Multinational Enterprises, Markets and Institutional Diversity Edited by Alain Verbeke, Rob Van Tulder and Sarianna Lundan

Voume 10: The Future of Global Organizing - Edited by Rob van Tulder, Alain Verbeke and Rian Drogendijk

Volume 11: The Challenge of BRIC Multinationals - Edited by Rob van Tulder, Alain Verbeke, Jorge Carneiro and Maria Alejandra Gonzalez-Perez

Volume 12: Distance in International Business: Concept, Cost and Value Edited by Alain Verbeke, Jonas Puck and Rob van Tulder

Volume 13: International Business in the Information and Digital Age - Edited by Rob van Tulder, Alain Verbeke and Lucia Piscitello

Volume 14: International Business in a VUCA World: The Changing Role of States and Firms - Edited by Rob Van Tulder, Alain Verbeke and Barbara Jankowska

Volume 15: The Multiple Dimensions of Institutional Complexity in International Business Research - Edited by Alain Verbeke, Rob van Tulder, Elizabeth L. Rose and Yingqi Wei 
PROGRESS IN INTERNATIONAL BUSINESS

RESEARCH VOLUME 16

\title{
INTERNATIONAL BUSINESS IN TIMES OF CRISIS
}

\section{Tribute Volume to Geoffrey Jones}

\author{
EDITED BY \\ ROB VAN TULDER
}

Erasmus University, The Netherlands

\section{ALAIN VERBEKE}

University of Calgary, Canada

\section{LUCIA PISCITELLO}

Politecnico di Milano, Italy

\section{JONAS PUCK}

WU Vienna, Austria

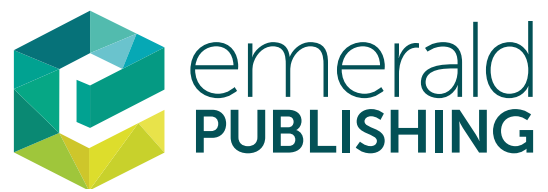

United Kingdom - North America - Japan India - Malaysia - China 
Emerald Publishing Limited

Howard House, Wagon Lane, Bingley BD16 1WA, UK

First edition 2022

Editorial matter and selection (C) 2022 Rob van Tulder, Alain Verbeke, Lucia Piscitello and Jonas Puck.

Individual chapters (C) 2022 the authors.

Published under exclusive licence by Emerald Publishing Limited.

\section{Reprints and permissions service}

Contact: permissions@emeraldinsight.com

No part of this book may be reproduced, stored in a retrieval system, transmitted in any form or by any means electronic, mechanical, photocopying, recording or otherwise without either the prior written permission of the publisher or a licence permitting restricted copying issued in the UK by The Copyright Licensing Agency and in the USA by The Copyright Clearance Center. Any opinions expressed in the chapters are those of the authors. Whilst Emerald makes every effort to ensure the quality and accuracy of its content, Emerald makes no representation implied or otherwise, as to the chapters' suitability and application and disclaims any warranties, express or implied, to their use.

\section{British Library Cataloguing in Publication Data}

A catalogue record for this book is available from the British Library

ISBN: 978-1-80262-164-8 (Print)

ISBN: 978-1-80262-163-1 (Online)

ISBN: 978-1-80262-165-5 (Epub)

ISSN: 1745-8862 (Series)

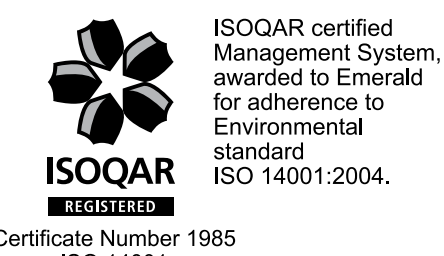

ISO 14001

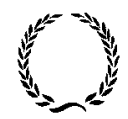

INVESTOR IN PEOPLE 


\section{CONTENTS}

List of Figures ix

List of Tables $x i$

About the Contributors xiii

Preface $x x v$

INTRODUCTION

Chapter 1 International Business in Times of Crisis:

What Perspective to Take?

Rob van Tulder, Alain Verbeke, Lucia Piscitello and Jonas Puck

\section{PART I}

THE LONGITUDINAL PERSPECTIVE - THE IMPORTANCE OF HISTORICAL IB STUDIES

Chapter 2 Crises and International Business

Geoffrey Jones

Chapter 3 Crises in International Business: A New Perspective Mark Casson

Chapter 4 History Matters

Mira Wilkins

Chapter 5 Crises, Emerging Market Firms, and Global Value Chain Resilience

Pavida Pananond

Chapter 6 Business Groups: Panics, Runs, Organ Banks and Zombie Firms

Asli M. Colpan and Randall K. Morck

Chapter 7 Take a Look at Yourself: International Business and the De-globalization Crisis

Michael A. Witt 
Chapter 8 Extraordinary Risk Management in International Business Strategy

Teresa da Silva Lopes

\section{PART II}

\section{THE MICRO-PERSPECTIVE - SELF-INFLICTED CRISES}

Chapter 9 How Companies Respond to Self-inflicted Crises.

A Comparison between Countries, Types of Crises, and Response Strategies

Marc Oberhauser and Marcus Conrad

Chapter 10 Learning Processes During Re-internationalization: A Case Study of Chinese SMEs Honglan Yu, Margaret Fletcher and Trevor Buck

Chapter 11 Switching Governance Modes to Improve the Resilience of Global Value Chains Against External Disruptions Wenyan Yin and Hwy-Chang Moon

\section{PART III}

\section{MESO-LEVEL PERSPECTIVE - SECTORAL CRISES}

Chapter 12 How to Be Smart: Leveraging Digital FDI to Address Risk Through Growing Capacity and Competitiveness Matthew Stephenson, Lorraine Eden, Michael Kende, Fukunari Kimura, Karl P. Sauvant, Niraja Srinivasan, Lucia Tajoli and James Zhan

Chapter 13 COVID-19 Crisis, Digitalization and Localization Decisions

Rubina Romanello and Valerio Veglio

Chapter 14 Serial Nonlinear Internationalization Before and During the COVID-19 Pandemic: Case Study Evidence From Estonia

Tiia Vissak

Chapter 15 Evolution of Consumption and Retail Transformation - The Emergence of New Institutional Order for the Future of Retailing Anna Karhu, Elina Pelto and Lauri-Matti Palmunen 
Chapter 16 Consumer Vulnerability During COVID-19: The Impact of Fear and Age on Consumer Behavior and Business Strategy

Helena Sá Domingues, Marcelo Augusto Linardi,

Susana Costa e Silva and Paulo Duarte

Chapter 17 Reassessing the Impact of the 2008 Financial Crisis on Global Foreign Direct Investment: Empirical Evidence and Theoretical Implications

Guoyong Liang

Chapter 18 Nexus of Debt Financing, Investment and Policy Intervention: Impact of Covid-19 Pandemics on CAREC Member Countries

Muhammad Ayub Mehar

PART IV

MACRO-LEVEL PERSPECTIVE - SYSTEMS CRISES AND COUNTRY RISKS

Chapter 19 Globalization in a COVID-19 Afflicted World Marian Gorynia, Jan Nowak, Piotr Trapczyński and Radostaw Wolniak

Chapter 20 Host-country Risk Dynamics and Foreign Direct Investments

Vera Kunczer, Thomas Lindner and Jonas Puck

Chapter 21 Strategies to Face Brexit: The Case of Polish Companies

Barbara Jankowska, Aleksandra Kania and Katarzyna Mroczek-Dabrowska

Chapter 22 Polish Companies and the Uncertainty over Brexit's Regulatory Void: Adaptive Strategies Toward the Unknown Anna Matysek-Jędrych and Katarzyna Mroczek-Dąrowska

Chapter 23 The Paradox of Distance - New Zealand Businesses During Covid-19

Benjamin Fath, Antje Fiedler, Noemi Sinkovics and Rudolf R. Sinkovics 


\section{PART V \\ EXOGENOUS CRISES - NATURAL DISTASTERS AND EMERGENCIES}

Chapter 24 Managers' Identification of Natural Disaster Risks: Findings from a Survey of 18 Countries

Chang Hoon Oh and Jennifer Oetzel

Chapter 25 A Taxonomy of Corporate Emergency

Responsibility to Ensure Social Sustainability Post-shock

Francisco Javier Forcadell and Elisa Aracil

Chapter 26 An Enterprise Risk Model for COVID-19

Crisis Effects - The Hungarian Experience

Péter Juhász and Ágnes Szabó

Chapter 27 Doing Business in a Distant Paradise Adam Grzywacz, Matgorzata Kuczara and

Aleksandra Wasowska 


\section{LIST OF FIGURES}

Fig. 1.1. Global Fluctuations (in GDP, Trade and FDI) in the Post 1989 World.

Fig. 1.2. Top Global Risks by Impact.

Fig. 1.3. Research Approaches to Analyze Crises in IB. 10

Fig. 1.4. The Historical Perspective in IB Journals $(N=172) . \quad 13$

Fig. 1.5. Self-inflicted Crises Covered in IB Journals $(N=59) . \quad 14$

Fig. 1.6. Sectoral Crises Covered in IB Journals $(N=105)$.

Fig. 1.7. Systems Crises and Country Risks Covered in IB Journals $(N=77)$.

Fig. 1.8. Exogenous Crises: Natural Disasters, Emergencies and Wars Covered in IB Journals $(N=319)$.

Fig. 8.1. FSA Framework for Extraordinarily Risky Environments. 106

Fig. 9.1. Distribution of Crisis Response Strategies Across the Different Types of SIC.

Fig. 9.2. Distribution of Crisis Response Strategies Across Countries. 123

$\begin{array}{ll}\text { Fig. 10.1. The Research Process. } & 137\end{array}$

Fig. 10.2. Summary of Thematic Analysis. 141

Fig. 10.3. Changes in Knowledge Acquisition Process for Case Firms. 149

Fig. 10.4. Changes in Information Distribution Process. 151

Fig. 10.5. Changes in Information Interpretation Process. 154

Fig. 11.1. A Framework for Reconfiguring Global Value Chains. 171

Fig. 12.1. G20 Adoption of 33 Digital FDI measures (01/01/2020 to 05/01/2021). 196

Fig. 12.2. Digital FDI Framework. 197

Fig. 12.3. DEP Methodology. 199

Fig. 12.4. Five Dimensions of the SMART Test. 200

Fig. 12.5. G20 Average Inward Foreign Direct Investment (IFDI) Capital Received Per Digitally Enabling Sector (USD million). 206

Fig. 12.6. G20 Average Share of Capital Received in Digitally Enabling Sectors (Out of Total Capital Received for IFDI Projects). 207

Fig. 12.7. G20 Average Number of IFDI Projects Per Digitally Enabling Sector.

Fig. 12.8. G20 Average Share of IFDI Projects in Digitally Enabling Sectors (Out of Total Number of IFDI Projects). 208

Fig. 13.1. The Most Digitalized Business Function Nowadays. 261

Fig. 13.2. The Expected Digitalization Impact on Business Functions. 262

Fig. 13.3. Expected Digitalization Impact on Autonomy, Geographic Dispersion and on Monitoring and Control of Business Functions Abroad. 
Fig. 13.4. Digitalization Impact on Linguistic Barriers. 264

Fig. 13.5. Digitalization Impact on Process Standardization. 264

Fig. 13.6. Digitalization Impact on Enterprise Culture. 265

Fig. 13.7. Digitalization Impact on the Relationships with Foreign Markets. 265

Fig. 15.1. Institutional Logics and the Evolution of Retailing $\begin{array}{ll}\text { and Consumption. } & 303\end{array}$

Fig. 17.1. Global FDI Inflows, 1990-2020 (Billions of Dollars). 344

Fig. 17.2. FDI Inflows by Major Grouping of Economies, 2007-2020 (Billions of Dollars). $\quad 345$

Fig. 17.3. Share of BRICS in Global FDI Flows, 2005-2020 (Percent). 347

Fig. 18.1. Debt Financing, Fiscal Policy and Investment Simultaneity in the System. $\quad 366$

Fig. 21.1. Pre-Brexit Strategies of Polish Companies. 414

Fig. 21.2. Downsizing Activities. 416

Fig. 22.1. Uncertainty over Institutional Agility in the UK Versus Uncertainty Over EU-UK Relationship. 426

Fig. 23.1. The Development of New Zealand's Exports During Covid-19. 433

Fig. 25.1. Daily Confirmed Deaths per Million People Over the Sample Period. Spain Heaviest Affected Country Over the Sample Period. 477

Fig. 25.2. Study Timeline. The Empirical Study Does Not Cover this Period.

Fig. 25.3. Companies Analyzed. Distribution of the Number of Actions and Response Time Per Company Analyzed.

Fig. 25.4. A Content-based Classification of CER Actions During the COVID-19 Pandemic in Spain 2020.

481

Fig. 25.5. Distribution of Companies Analyzed by Sector. 482

Fig. 25.6. CER Actions in Partnership. 482

Fig. 25.7. A Taxonomy for CER Post-shock. 483

Fig. 25.8. CER Actions and Social Impact. 486

Fig. 26.1. Share of Hungarian Enterprises Expecting Adverse COVID-19 Effects 2020 (Percent).

Fig. 26.2. How Has the Pandemic Impacted the Way Your Organization is Prioritizing the Following Business Initiatives? 508

Fig. 26.3. Corporate Risk Overview of the COVID-19 Pandemic. 508 


\section{LIST OF TABLES}

Table 3.1. Classification of Crises. $\quad 38$

Table 3.2. Three Key Groups of Human Agents in a Crisis. 39

Table 9.1. Initial Response Strategies. 118

Table 9.2. Distribution of SIC Across Countries and Years. 120

$\begin{array}{ll}\text { Table 9.3. Classification of LRS. } & 121\end{array}$

Table 9.4. MNCs with the Highest Number of SIC. 122

Table 10.1. Three Processes of Information Distribution Within 135

Table 10.2. Sample Overview and Data Collection. 139

Table 10.3. Initial International Experience and Reasons
for De-internationalization.

Table 10.4. Differences of Learning between Complete and Partial Re-internationalizers. 155

Table 12.1. Summary of SMART Test and Tools. 205

Table 13.1. Description of Sampled Firms for the In-depth Interviews. 259

$\begin{array}{ll}\text { Table 13.2. Description of Variables. } & 260\end{array}$

Table 14.1. Opportunities and Threats Emerging Due to the
Covid-19 Pandemic.

Table 14.2. Studied Firms' Serial Nonlinear Internationalization Before and During the Covid-19 Pandemic. 283

Table 16.1. Descriptive Statistics of Consumer Vulnerability Scale. 321

Table 16.2. Comparison of Age Group Results Before COVID-19. 322

Table 16.3. Comparison of the Country of Residence Results Before COVID-19.

Table 16.4. Comparison of Age Group Results in COVID-19 Aggravation Factors.

Table 16.5. Comparing Country of Residence Results in COVID-19 Aggravation Factors.

Table 16.6. Spearman's Correlation Between Fear of COVID-19 and CV Aggravation Factors. 325

Table 18.1. GDP Growth (\%). 356

Table 18.2. Gross Debt (\% of GDP). 356

Table 18.3. Intersection of CAREC and ECO Countries. 357

Table 18.4. Growth and Fiscal Position. 358

Table 18.5. Fiscal Packages for Covid-19 in CAREC Member Countries (as on January 25, 2021). 363

Table 18.6. Total Cases of COVID-19 in CAREC Region as on
January 28, 2021.

Table 18.7. Dependent Variable: GROW in Percentage. 369 
Table 18.8. Dependent Variable: TXTOGDP. 370

Table 18.9. Dependent Variable: Net INONFN as \% of GDP. 371

Table 19.1. Globalization Scenarios Under Covid-19 Pandemic Conditions.

Table 21.1. Grouping Factors. 413

Table 21.2. Group Mean Values. 413

Table 21.3. Characteristics of Companies Undertaking Different Pre-Brexit Strategies. $\quad 415$

Table 22.1. Sample Breakdown. 423

Table 22.2. Factors Used in the K-means Cluster Analysis. 423

Table 22.3. Between and Within Cluster Variance. 424

Table 22.4. Means for Grouping Measures in Respective Clusters. 425

Table 23.1. Case Studies and Key Themes. 438

Table 24.1. Sample Description. 459

Table 24.2. Summary Statistics and Correlation Matrix. 462

Table 24.3. Managers' Identification of Natural Disaster Risks. 463

Table 25.1. Evaluation of CER Strategies Leading to Social Sustainability Through the CER Framework. 485

Table 26.1. Different Appearances of COVID-19 Related Risks. 494

Table 26.2. The Most Common Appearances of COVID-19 Related Risks in Hungary (Percent). 494

Table 26.3. Top Challenges of Work from Home During the Lockdown. 497

Table 26.4. Changes Since the Start of COVID-19 Crisis. 497 


\section{ABOUT THE CONTRIBUTORS}

Elisa Aracil, PhD, is a Professor and Researcher at the Universidad Pontificia Comillas (Madrid). Her research focuses on the competitive advantages of sustainability at an organizational level. She has published in the Journal of Cleaner Production, Finance Research Letters, Technological Forecasting and Social Change, Business Strategy \& the Environment, Corporate Social Responsibility and Environmental Management, among other. She holds 10 years of investment banking experience.

Trevor Buck is a Research Professor at the Adam Smith Business School, University of Glasgow. His research has appeared in the Academy of Management Journal and in top IB journals such as Journal of International Business Studies (six times). His current research interests include platform business models, platform reviews as signals, executive pay and firm strategies in extremely uncertain environments.

Mark Casson is a Professor of Economics in the Department of Economics and the Henley Business School at the University of Reading, and the Co-Director of the Centre for Economic Institutions and Business History. He is the Consulting Editor of the Journal of World Business and International Business Review. His recent books include Compassionate Capitalism: Business and Community in Medieval England (coauthored, 2020); The Multinational Enterprise: Theory and History (2018); and The Theory of International business: Economic Models and Methods (2016).

Asli M. Colpan is a Professor of Corporate Strategy at the Graduate School of Management and Graduate School of Economics, Kyoto University, Japan. Previously, she was the Alfred Chandler Visiting Scholar at Harvard Business School and a Visiting Scholar at the Department of Political Science at MIT. Her research interests include corporate strategy, corporate governance, business history, and especially the evolution of large enterprises in developed and emerging economies. She co-edited The Oxford Handbook of Business Groups (with Takashi Hikino and James Lincoln, OUP, 2010), Business Groups in the West (with Takashi Hikino, OUP, 2018) and Business, Ethics and Institutions: The Evolution of Turkish Capitalism in Global Perspectives (with Geoffrey Jones, Routledge, 2020). Her work has also been published in such journals as Industrial and Corporate Change, Journal of Management Studies, Strategic Management Journal, Business History, Journal of Business Ethics, and Corporate Governance: An International Review.

Marcus Conrad is a Research and Teaching Associate at the Department of International Management at the School of Business, Economics and Society, Friedrich-Alexander-University of Erlangen-Nürnberg, Germany. His main research interests include Corporate Misconduct, Corporate Scandals, Corporate 
Social Irresponsibility, and Business Ethics. Former publications dealt with topics such as corporate social responsibility of defense companies, the Volkswagen emission scandal, crisis communication strategies, and corporate tax strategies. In Fall 2021, he successfully defended his doctoral dissertation.

Helena Sá Domingues has a BSc in Business Management and is currently an MSc Student in Business Management at Católica Porto Business School, Universidade Católica Portuguesa, Portugal.

Paulo Duarte holds a $\mathrm{PhD}$ in Management and is associate Professor at the Faculty of Human and Social Sciences of Universidade da Beira Interior, Portugal. He heads the MSc in Marketing and is Research Line Coordinator at NECE - Research Centre in Business Sciences. His research interests include consumer behaviour, the intersection between Psychology and Marketing, namely consumer and buying behaviour, satisfaction, and branding across sectors and industries, both offline and online.

Lorraine Eden is a Professor Emerita of Management and Research Professor of Law at Texas A\&M University. Her current research interests are transfer pricing and MNE strategies in the digital economy. She has been Editor-in-chief of JIBS, President of the Academy of International Business, and is currently Dean of the AIB Fellows. She has a PhD in Economics from Dalhousie University.

Benjamin Fath, PhD, is a Senior Lecturer at The University of Auckland Business School. He has researched innovation, internationalization, and growth of NZ businesses for over a decade. He teaches Research Methods on the MBA programme. He has facilitated workshops across New Zealand for practitioners on partner strategy in Asia in collaboration with the Asia New Zealand Foundation and ExportNZ. His work has been published in journals including Australian Journal of Management, Human Relations, International Small Business Journal, and the European Journal of Industrial Relations.

Antje Fiedler, PhD, is a Senior Lecturer at The University of Auckland Business School. Her research interests include growth and internationalization of firms, with a focus on emerging Asia, and employment relations. She is a Member of the New Zealand Asia Institute and the Director of the China Studies Centre of The University of Auckland. She is a Member of the Academic Advisory Team of the Southeast Asia Centre of Asia-Pacific Excellence. Her work has been published in international journals, such as New Political Economy, Human Relations, International Small Business Journal, and the Industrial Relations Journal.

Margaret Fletcher, $\mathrm{PhD}$, is a Senior Lecturer in International Business at the Adam Smith Business School, University of Glasgow, UK. Her research interests include internationalization, international entrepreneurship, and SME internationalization policy. She has published in the Journal of Word Business, Journal of International Marketing, International Business Review, International Small Business Journal, Transnational Corporations Journal, International Journal of 
Entrepreneurial Behaviour and Research, Journal of Small Business and Enterprise Development, Journal of European Industrial Training and Venture Capital.

Francisco Javier Forcadell, $\mathrm{PhD}$, is an Associate Professor of Management at the Rey Juan Carlos University (Spain) and a Professor at ESIC Business and Marketing School (Spain). He has held visiting professorship at some universities around the world. His research and teaching revolve primarily around Strategic Management and Corporate Social Responsibility. He was a Consultant at the Spanish Economy Ministry. He is the author of several international publications, focusing on diverse aspects of CSR, innovation, and corporate strategy. He has published in several top journals, including Research Policy, Long Range Planning, Journal of World Business, Technological Forecasting \& Social Change, Business Strategy and the Environment, or Journal of Business Ethics. He presents his research regularly in international conferences such as the Academy of Management Society, Strategic Management Society, EURAM, or Iberoamerican Academy of Management.

Marian Gorynia is a Full Professor at the Poznań University of Economics and Business (Poland), and a Former Rector of this university in the years 20082016, a Former Vice-rector for research in 2002-2008. He is the Vice-chair of the Scientific Excellence Council for the 2020-2023 term, the institution which supervises post-doc degrees in Poland. His research focuses on firm competitiveness, international business strategies, and globalization. He has published his research in many reputable publishing houses and journals, including the International Business Review, Eurasian Geography and Economics, Communist and Post-Communist Studies, and Post-Communist Economies.

Adam Grzywacz is a PhD candidate at the Doctoral School of Social Sciences, University of Warsaw. He conducts research and teaches at the University's Faculty of Management, where he earned his BA and MA. He is also a Member of the European International Business Academy.

Barbara Jankowska, PhD, is a Full Professor at the Poznan University of Economics and Business, Poland, the Head of the Department of International Competitiveness. She was the EIBA President for 2018. She is the National Representative of Poland in EIBA - European International Business Association, and the Member of AIB - Academy of International Business, IT\&FA - International Trade and Finance Association. Her research areas are: international business (FDI, innovation performance of MNEs), Industry 4.0 and business clusters. She is an author and co-author of -research papers in (e.g.) European Journal of International Management, European Planning Studies, Entrepreneurial Business and Economics Review, Journal of East European Management Studies, Post-Communist Economies and of chapters published by (e.g.) Emerald, Routledge, and Springer.

Geoffrey Jones, is the Isidor Straus Professor of Business History, and Faculty Chair of the School's Business History Initiative. He holds degrees of BA, MA and PhD from Cambridge University, UK. He has an honorary Doctorate in Economics and Business Administration from Copenhagen Business School, Denmark, and an 
honorary $\mathrm{PhD}$ from the University of Helsinki, Finland. He taught previously at the London School of Economics, and Cambridge and Reading Universities in the UK, and at Erasmus University Rotterdam in the Netherlands. He has held Visiting Professorships at Gakushuin University, Tokyo, and Universidad de los Andes, Bogota, and is an Affiliate Professor of Ritsumeikan University, Kyoto. Elsewhere at Harvard, he serves on the Executive Committee of the Harvard Center for African Studies, the Faculty Committee of the Reischauer Institute of Japanese Studies, and on the Policy Committee of the David Rockefeller Center for Latin American Studies.

Péter Juhász, PhD, CFA, Corvinus University of Budapest, Hungary. He serves as an Associate Professor of Finance, and his research interest covers corporate finance, business valuation, enterprise risk management, business performance and competitiveness analysis, and ethics in finance. He also acts as a Management Consultant and a Trainer regularly and has been a Board Member for the CFA Society Hungary for more than a decade.

Aleksandra Kania, $\mathrm{PhD}$, is an Assistant Professor at the Department of International Competitiveness at Poznan University of Economics and Business. She participated in national and international research and educational projects and coordinated the project within Erasmus + Strategic Partnership. Her research focuses on internationalization, coopetition, and innovation. She is a former Rotary Scholar in Mannheim, Germany and an active EIBA member. For her doctoral thesis on innovative clusters in Baden-Württemberg and Greater Poland, she won the first prize in the national competition funded by Wolters Kluwer. Before her current research role, she worked for MNEs in Poland and Germany.

Anna Karhu is a Project Manager at the Pan-European Institute at Turku School of Economics, University of Turku, Finland. Her research interests include institutional complexity and institutional change in industry development.

Michael Kende is a Senior Fellow and a Visiting Lecturer at the Graduate Institute of International and Development Studies, Geneva, a Senior Advisor at Analysys Mason, and a Digital Development Specialist at the World Bank Group. He is the former Chief Economist at the Internet Society, and was a Partner at Analysys Mason, an Assistant Professor at INSEAD, and the Director of Internet Policy Analysis at the Federal Communications Commission. He has a $\mathrm{PhD}$ in Economics from MIT, and BA from Bowdoin College.

Fukunari Kimura is a Professor, Faculty of Economics, Keio University, Tokyo, Japan since 2000 and the Chief Economist, Economic Research Institute for ASEAN and East Asia since 2008. He received his Bachelor of Law from the Faculty of Law, University of Tokyo in 1982, MS and PhD in Economics from the University of Wisconsin-Madison respectively in 1990 and 1991. He was a Researcher at the International Development Center of Japan (1982-1986), an Assistant Professor at the Department of Economics, State University of New York at Albany (1991-1994), and an Associate Professor at the Faculty of Economics, Keio University (1994-2000). He was also the President, Japan Society of International Economics (2010-2012) and the Representative Director, Tokyo Center for Economic Research (2012-2014). 
Malgorzata Kuczara is a $\mathrm{PhD}$ candidate at the Faculty of Management, University of Warsaw. She specializes in board research, corporate governance, and strategic management.

Vera Kunczer is a Post-doctoral Researcher at the Institute for International Business at WU Vienna, Austria. She earned her PhD from WU Vienna in 2020 and was a Visiting Researcher at the Department of Global Economics and Management of the University of Groningen. Her research interests focus on international strategy, particular in response to political and social developments, and on developmental effects of firms' international operations. In her dissertation, she investigated how political dynamics and anti-foreignism influence firms' foreign investment strategies. In 2020, her dissertation proposal was awarded the AIB Best Doctoral Dissertation Proposal Award. She was also recognized as a best reviewer, was nominated for Best Paper Awards as well as for the Best Dissertation Award at the AOM Annual Meeting. So far, her work has been published in the Journal of International Business Policy.

Guoyong Liang is a Senior Economist at the United Nations Conference on Trade and Development. He holds a PhD from Rotterdam School of Management, Erasmus University. He is an author of 14 issues of World Investment Report and has published widely with a focus on international economic relations and development.

Marcelo Augusto Linardi is a PhD Candidate in Marketing and Strategy at Universidade da Beira Interior. He is a Researcher of NECE-UBI - Research Centre for Business Sciences. He is a Guest Assistant at Católica Porto Business School. His research interests include consumer behavior, consumer vulnerability, consumer empowerment, and artificial intelligence.

Thomas Lindner is a Full Professor of International Management at University of Innsbruck (Austria). He was an Assistant Professor at the Institute for International Business at WU Vienna, and a Visiting Assistant Professor at NYU Stern before joining Innsbruck. His research covers strategy, international finance, and research methods. In strategy, he investigates the interaction between government policy and firm strategy, post-internationalization behavior of firms, and organizational responses to liabilities of foreignness. His research in international finance deals with capital structure in international firms, valuation of cross-border bond issues, and project finance. He also works on research methods for international business and applications of artificial intelligence in multinational companies. His research has been published in the Academy of Management Journal, International Business Review, Journal of International Business Policy, Journal of International Business Studies, Journal of International Management, and the Journal of World Business.

Teresa da Silva Lopes is a Professor of International Business and Business History and the Director of the Centre for Evolution of Global Business and Institutions (CEGBI) at the University of York, United Kingdom. She is also the President of the European Business History Association (EBHA). Her research focuses on international business strategy, and the evolution of multinationals and their impact on 
globalization and de-globalization. Her books include The Routledge Companion to the Makers of Global Business (co-edited, 2020); Trademarks, Brands and Competitiveness (co-edited, 2010); Global Brands: The Evolution of Multinationals in Alcoholic Beverages (2007); and Internationalization and Concentration in Port Wine, 1945-1995: A Transaction Costs Approach (1997). She has published in both international business and business and economic history journals such as Journal of International Business Studies, Business History Review, Business History and Economic History Review.

Anna Matysek-Jędrych, $\mathrm{PhD}$, is an Assistant Professor at the Poznań University of Economics and Business, Department of International Competitiveness. Her main research areas include macroeconomics and political aspects of international economics. She is the Director of the Executive MBA Pro-gram held in cooperation with Georgia State University in Atlanta, United States. Her expertise covers financial markets, institutional framework and its impact on the economy's performance. Recently, she joined a research team on a project studying Brexit consequences on EU27 cohesion and she conducts her own research in institutional determinants of macroprudential policy efficiency. She is the author of more than 50 scientific articles, chapters, and monographs, including 2 research projects for the National Bank of Poland (winner of grant com-petition among economists from Poland). She is also a Member of the editorial and review board of the Journal of Eastern European and Central Asian Research (Webster University), the International Journal of Emerging Markets, and the Cross-Cultural \& Strategic Management.

Muhammad Ayub Mehar, PhD, is associated with the Employers' Federation of Pakistan as an economic advisor. Currently, he is serving as a Professor in Iqra University Karachi. He has completed and working on various research assignments for Asian Development Bank Institute. He has served as an economic advisor and the Director General in the Federation of Pakistan Chambers of Commerce and Industry for 7 years, and the economic advisor of the ECO Chamber of Commerce for 2 years. In recent past, he contributed chapters in the books published by the Asian Development Bank Institute (Tokyo: 2020) on 'Measuring Impacts and Financing Infrastructure Development', 'Economic Integration among CAREC Member Countries', and 'Environmental, Social, and Governance Investment: Opportunities and Risks for Asia'. In recognition of his expertise, the Technology Policy and Assessment Center at Georgia Institute of Technology acknowledged his membership in the distinguished panel of international experts for Indicators of Technology-based Competitiveness, which is a project of the US National Science Foundation, United States Government.

Hwy-Chang Moon (PhD) is an Overseas Professor at Beijing Normal University and a Professor Emeritus in the Graduate School of International Studies at Seoul National University. Currently, he is also the Chairperson of the Institute for Policy and Strategy on National Competitiveness (IPSNC) at aSSIST, a Consultant to United Nations Conference on Trade and Development (UNCTAD), and an Honorary Ambassador of Foreign Investment Promotion for South Korea. He has been frequently invited to deliver lectures at several universities 
including Stockholm University and Helsinki School of Economics (currently Aalto University) in Europe, Keio University and Beijing Normal University in Asia, and The State University of New York at Stony Brook and Stanford University in the United States. He has conducted many consulting/research projects for multinational companies), international organizations, and governments. He has published numerous articles and books, including The Strategy for Korea's Economic Success (2016, Oxford University Press) and The Art of Strategy: Sun Tzu, Michael Porter, and Beyond (2018, Cambridge University Press).

Randall K. Morck is Jarislowsky Distinguished Chair and Distinguished University Professor at the University of Alberta. He earned an honors BSc summa cum laude (Applied Mathematics and Economics) at Yale and a PhD (Economics) at Harvard. He is a Research Associate with the National Bureau of Economic Research, a Senior Fellow and the Vice President of the Asian Bureau of Financial and Economics Research; a Research Member with the European Corporate Governance Institute, a Senior Research Associate in Harvard Law School's Labor and Worklife Program, an Inaugural Fellow with the International Corporate Governance Society; and Yangtze Scholar at Wenlan School of Economics. He has been Mackenzie King Visiting Chair at Harvard, Schoen Visiting Professor of Finance at Yale, Bank of Canada Research Fellow, Monetary Authority of Singapore Visiting Research Professor, and James Riady Visiting Professor at National University of Singapore. His over 100 papers have over 46,000 citations.

Katarzyna Mroczek-Dąbrowska, $\mathrm{PhD}$, is an Associate Professor at the Poznan University of Economics and Business, Department of International Competitiveness. Her main research areas include international competitiveness of firms and industries, transaction costs, and the internationalization process of industries. She is the author and co-author of published works covering amongst others the Global Financial Crisis and its impact on strategies of Polish enterprises and the impact of Brexit on the EU-27 cohesion. She is a member of the European International Business Academy and works on several international research and teaching projects cooperating with universities and consulting companies in the United Kingdom, Belgium, and Slovenia.

Jan Nowak holds a $\mathrm{PhD}$ degree in Organization and Management Sciences (University of Warsaw). Currently, he is a University Professor and the Rector of the European University of Business in Warsaw, Poland. He is a former Full Professor at the University of New Brunswick in Canada, the University of the South Pacific in Fiji and the Central European University in Hungary. He specializes in marketing and international business areas, in which he has many years of international academic, training, administrative, and consulting experience. He has authored or co-authored more than 70 articles in academic journals and conference proceedings, 5 books and many chapters in collective works, reports, and similar publications.

Marc Oberhauser is Assistant Professor of Management at ESCP Business School, Madrid and affiliated postdoctoral researcher at the Department of International Management at the School of Business, Economics and Society, 
Friedrich-Alexander-University of Erlangen-Nürnberg, Germany. His main research interests include Corporate Misconducts, CSR, Business Ethics and Emerging Markets. Former publications dealt with topics such as the CSR orientation of future top managers, and the regaining of stakeholder legitimacy after a corporate misconduct.

Jennifer Oetzel is a Professor in the Department of Management at American University's Kogod School of Business. Her research focuses on understanding how firms manage risk. More specifically, she examines how businesses can best manage violent conflict, natural disasters, and other discontinuous risks and how promoting economic and social development, and, in some cases peace building, can minimize business risk and positively contribute to the local/regional community and the overall business environment. Her overall body of research includes more than 25 articles and book chapters. Her research work has appeared in the Strategic Management Journal, Organization Science, and the Journal of International Business, among other outlets. She serves on the Editorial Boards for the Strategic Management Journal, Journal of International Business Studies, Journal of World Business, and Business \& Society. She received her PhD degree in Strategic Management from the University of North Carolina at Chapel Hill.

Chang Hoon Oh is William and Judy Docking Professor of Strategy at the University of Kansas School of Business. He previously was the William Saywell Professor at the Beedie School of Business, Simon Fraser University, Vancouver, Canada. Before receiving $\mathrm{PhD}$ degree from the Kelley School of Business at Indiana University, he was a Marketing Manager of Samsung Electronics and Samsung Corporation. He published more than 60 papers on topics such as business in challenging environments, business continuity and sustainability, and globalization versus regionalization. His research has been supported by the Social Sciences and Humanities Research Council of Canada (SSHRC), Canadian International Resources and Development Institute (CIRDI), and the National Research Foundation of Korea (NRF). He collaborated with World Wildlife Fund of Nature (WWF) and United Nations Development Program (UNDP). Currently, he is the Co-Editor-in-Chief of Multinational Business Review and a Consulting Editor of the Journal of World Business.

Lauri-Matti Palmunen is a University Lecturer in Management and Organization at Turku School of Economics, University of Turku, Finland. His research interests include decision-making, cognition, and routines in an organizational context.

Pavida Pananond is a Professor of International Business at Thammasat Business School, Thammasat University. Her research focuses on the internationalization process, global value chain, and economic upgrading, with specific reference to strategies of firms from emerging economies. She has authored over 40 publications, which appear in journals like Global Strategy Journal, Multinational Business Review, and Journal of International Management. Her commentaries have been published, and cited in local and international media, including The Economist, Financial Times, and the $B B C$. She is a frequent speaker at international public forums and investor conferences. She is an Honorary Adviser to Asia New Zealand 
Foundation and serves on a number of editorial boards of international academic journals. She is an Independent Director at Precious Shipping Public Company Limited, Thailand's leading dry bulk carrier. She also provides briefings to diplomatic missions, chambers of commerce, and multinational companies.

Elina Pelto is a University Lecturer in International Business at Turku School of Economics, University of Turku, Finland. Her research interests include the impact of FDI on host industries, cross-border mergers and acquisitions, and institutional change.

Jonas Puck is a Full Professor at the WU Vienna University of Economics and Business and was the Founding Head of WU's Institute for International Business. Before joining WU, he held positions at Nuremberg University, Germany, the University of New South Wales, Australia, the University of International Business and Education, China and the Bradford University School of Management, UK. His current research interests lie in the overlaps of global strategy, finance, and political science. He serves on the Editorial Boards of the Journal of International Business Studies, Long Range Planning, International Business Review, European Management Journal, Journal of World Business, and the Multinational Business Review. His research has been published in journals such as the Journal of International Business Studies, Journal of Management Studies, Journal of World Business, and Human Resource Management (US), among others. In addition, he is the editor or author of six books and numerous book chapters.

Rubina Romanello is a Post Doc Research Fellow at the University of Udine (Italy), Department of Economics and Statistics. Her research focuses on early internationalization and born globals, SMEs internationalization strategies, Industry 4.0 technologies, smart and connected products, SME international competitiveness, public support and firm performance. She has published in journal outlets such as the Journal of Knowledge Management, Critical Perspectives on International Business, and Journal of International Entrepreneurship.

Karl P. Sauvant is an Adjunct Professor at Columbia Law School and a Resident Senior Fellow at the Columbia Center on Sustainable Investment, where he was the Founding Executive Director of CCSI's predecessor. He was the Director of UNCTAD's Investment Division where he created the annual World Investment Report. He is an AIB Fellow and EIBA Honorary Fellow, with a PhD from the University of Pennsylvania.

Susana Costa e Silva is an Associate Professor at Católica Porto Business School, Universidade Católica Portuguesa, Portugal, where she is teaching International Marketing and Marketing-related issues. She got her $\mathrm{PhD}$ from the University College Dublin, Ireland. She is a Member of the Research Centre in Management and Economics (CEGE). She is an Adjunct Professor at University of Saint Joseph, Macau. She is currently the National Representative for Portugal at EMAC and attends EIBA regularly. Her research interests include internationalization, marketing and consumer behavior, online retailing, and artificial intelligence. 
Noemi Sinkovics ( $\mathrm{PhD}$, University of Manchester) is a Senior Lecturer in International Business at University of Glasgow, Adam Smith Business School. Prior to that she worked at The University of Auckland, New Zealand and The University of Manchester, UK. Her research interests are theoretical and practical issues around entrepreneurship (including international and social entrepreneurship) and social, environmental, and economic upgrading in global value chains. Her work has been published in International Business Review, International Marketing Review, Journal of Business Research, Journal of World Business, Management International Review, Journal of International Management, European Journal of International Management, Journal of Interactive Marketing, Critical Perspectives on International Business and as chapter contributions to edited volumes.

Rudolf R. Sinkovics (PhD, WU-Vienna, Austria) is a Professor of International Business at University of Glasgow, Adam Smith Business School, and a Visiting Professor at LUT University, Finland. His research writing covers issues of inter-organizational governance, and the role of ICT, with a current focus on responsible business. His work has been published in journals such as Journal of International Business Studies, Management International Review, Journal of World Business, International Business Review, Journal of International Management, Journal of Business Research, Journal of International Marketing and International Marketing Review. He is the Editor-in-Chief for Critical Perspectives on International Business, Consulting Editor for Journal of World Business and an Associate Editor for Transnational Corporations and serves on a number of editorial boards.

Niraja Srinivasan is a Partner in the global transfer pricing practice at NERA Economic Consulting and is based in Washington, DC. Her research and consulting interests are transfer pricing controversy management for multinationals. Prior to NERA, she held tax leadership roles in Fortune 50 companies. She has a PhD in Applied Economics from the Wharton School, University of Pennsylvania.

Matthew Stephenson is the Policy and Community Lead for International Trade and Investment at the World Economic Forum, where he manages the Global Investment Policy and Practice initiative. Previously, he worked at the IFC, where he led advisory services on Outward FDI. He has a PhD from the Graduate Institute of International and Development Studies, a Masters from the Harvard Kennedy School, and a Bachelors from the University of Oxford.

Ágnes Szabó, PhD, Corvinus University of Budapest, Hungary. She works as an Assistant Professor for the Department of Business Studies at the Corvinus University of Budapest. Her field of research covers the economics of recreational sports and workplace health. Besides gaining experience in the private sector, she is also a Member of the Fittest Workplace Program and the Longevity Project since 2013 and 2019, which programs deal with corporate health promotion. 
Lucia Tajoli is a Professor of Economic Policy at the Department of Management Engineering of Politecnico di Milano. She is a Member of the Scientific Committee of the Observatory on Digital Export of Politecnico di Milano, and she is a Senior Research Fellow of the Institute for International Political Studies (ISPI) in Milan. Her research activity focuses on international trade, economic integration between countries and trade policies.

Piotr Trąpczyński is an Associate Professor at the Poznań University of Economics and Business (Poland), and Director of the International Business Centre of the consulting subsidiary of this university. His research focuses on firm competitiveness, internationalization performance and foreign market exits. He has published his research in many reputable publishing houses and journals, including the Journal of World Business, Journal of Business Research, International Business Review, European Management Journal, or the European Journal of International Management.

Valerio Veglio is an Assistant Professor of International Management at the Free University of Bozen (Italy). He carries out research on how firms perceive and react to the competitive threat caused by digitalization, with particular attention at exploring how new digital technologies such as Internet of Things and Big Data Analytics impact on the Configuration of Global Value Chains. He has published in Industrial Marketing Management, Scientometrics, and Journal of International Entrepreneurship.

Tiia Vissak is an Associate Professor at the University of Tartu, Estonia. She has published in various international journals, such as International Business Review, International Entrepreneurship and Management Journal, IEEE Access, Journal of International Entrepreneurship, Journal of East-West Business, and Review of International Business and Strategy, and in books by Emerald, Edward Elgar, Springer, Palgrave, Routledge, etc. She has also co-edited two books by Emerald (in 2013, "(Dis)Honesty in Management: Manifestations and Consequences" together with Prof Maaja Vadi and in 2009, "Research on Knowledge, Innovation and Internationalization" together with Prof Jorma Larimo). Her main research interests include internationalization processes, factors affecting foreign market entries, exits and re-entries (for instance, network relationships, decision-making logics, and changes in the business environment), and measurement and improvement of export performance.

Aleksandra Wąsowska is an Assistant Professor of Strategy and International Business at the Faculty of Management, University of Warsaw, where she obtained her PhD in Organization Studies. Her research interests include emerging market multinationals, diversity \& inclusion, internationalization of firms from post-communist countries, behavioral strategy and entrepreneurial decisionmaking. She has authored and co-authored numerous book chapters and papers in refereed academic journals, including Business History, the European Journal of International Management, and the Journal of East European Management Studies. She is a Member of the Academy of International Business (AIB) and the European International Business Academy (EIBA). 
Mira Wilkins is Professor of Economics Emerita at Florida International University. She is an Economic and Business Historian, who has been engaged in research and publishing in the field of international business history for slightly over six decades, that is from the late 1950s to the present. She has published four Harvard University Press books, two on US business abroad (published in 1970 and 1974) and two on the history of foreign investment in the United States (1989 and 2005). Her many other publications have included books and articles on a wide variety of different aspects of the history of international business, some focused on themes (for example, technological transfer, free standing companies, trademarks), regions (Europe, Latin America), countries (in particular, but not confined to Switzerland, the Netherlands, Japan, Australia, South Africa), industries (oil, electrification, insurance in particular), and specific companies (Ford Motor Company). Her research on the history of multinational enterprise is interdisciplinary. Although much of her fundamental work has been on the histories of foreign business in the United States and on US business abroad, her research has taken her around the world, from Canada to China, from Ghana to Guatemala, from Singapore to Saudi Arabia.

Michael A. Witt is a Senior Affiliate Professor of Strategy and International Business at INSEAD, Singapore. His research focuses on the influence of national institutional systems (varieties of capitalism) on firms and on the business and managerial implications of de-globalization and geopolitical conflict. He holds a $\mathrm{PhD}$ in political science from Harvard University.

Radosław Wolniak holds a PhD degree in Economics and is an Adjunct Professor at the Department of Innovation and Development at the University of Warsaw. His teaching and research interests revolve around multinational enterprises, foreign direct investment, and international marketing. He also has extensive consulting experience in the field of international investment and marketing. $\mathrm{He}$ has published his research in many reputable publishing houses and journals, including the International Business Review, Eurasian Geography and Economics, Communist and Post-Communist Studies, and Post-Communist Economies.

Wenyan Yin $(\mathrm{PhD})$ is an Assistant Professor at Seoul School of Integrated Sciences and Technologies (aSSIST) and Lecturer in the Graduate School of International Studies at Seoul National University. She also serves as a Consultant to UNCTAD of the United Nations. She has published a number of articles including those in the journals indexed by SSCI, A\&HCI, and SCOPUS. Her research areas are global value chain, foreign direct investment, international business strategy, and national competitiveness. She has also conducted many research projects related to the international competitiveness and foreign direct investment for firms and governments.

Honglan Yu, PhD, is a Lecturer in Management at the Huddersfield Business School, University of Huddersfield, UK. His research focuses on organizational learning, re-internationalization, and international failures. $\mathrm{He}$ is a recipient of the Lazaridis Institute Best Paper Award for International Entrepreneurship in the $46^{\text {th }}$ European International Business Academy (EIBA) conference, 2020.

James Zhan is a Senior Director of the Investment and Enterprise Division, United Nations Conference on Trade and Development and the Editor-in Chief of the World Investment Report and Transnational Corporations journal. 


\title{
PREFACE
}

\section{TRIBUTE TO PROFESSOR GEOFFREY G. JONES}

\author{
Rob van Tulder, Alain Verbeke, Lucia Piscitello and Jonas Puck
}

It is a privilege to dedicate Volume XVI of the Progress in International Business Research - PIBR book series to Professor Geoffrey G. Jones, the Isidor Straus Professor of Business History at the Harvard Business School, and Faculty Chair of the School's Business History Initiative. Professor Jones was educated at Corpus Christi College (University of Cambridge, UK). Prior to his appointment at the Harvard Business School (USA), he was a Professor of International Business History at the Economics Department of the University of Reading (UK).

Professor Jones' reputation as a formidable contributor to the domain of international business is at par with that of the seven other great institution builders in our field who were honoured in earlier PIBR volumes, namely Daniel G. Van Den Bulcke, Alan M. Rugman, Louis T. Wells, Rosalie L. Tung, Lorraine Eden, Peter J. Buckley and D. Eleanor Westney.

Professor Jones is the rare scholar who has successfully straddled the interdisciplinary divide between business history and international business. He is the Co-Editor of the renowned Business History Review, published by Cambridge University Press. He has published not only in all the leading business history journals, but also in the Journal of International Business Studies and other premier management journals such as the Strategic Management Journal.

Professor Jones is probably best known for his incisive books on multinational enterprise activity. He has authored 12 books and (co-) edited 28 other volumes. In 1996, he carved out mainstream academic space for the historical perspective of IB in his book The Evolution of International Business: An Introduction (published by Routledge). This book is still one of his best cited contributions. His book Multinationals and Global Capitalism published by Oxford University Press in 2004 has become the standard textbook on the history of multinational enterprises and it has been adopted at leading universities around the world. It has received over 1,000 citations in academic journals. It is also important to mention Professor Jones' authorship of more than one hundred Harvard Business School teaching cases and notes, which reflect a deep engagement with the practice of strategic and international management.

Professor Jones' long-standing and highly significant contributions to international business studies, drawing on business history methodology, are well recognized in the field. The great strength of Professor Jones' scientific oeuvre is the systematic acknowledgment of the complexities of international business. Throughout Professor Jones' writings, we find a strong emphasis on the need to address multinational enterprise complexity in its many appearances. One recent 
example includes analysis of the importance of oral histories to understand business trajectories (Jones \& Comunale, 2019). A second example is the study of the many difficulties associated with the greening of business and the development of sustainability-related strategies, which cannot simply be imposed by third parties (Jones, 2017, 2018). A third example, and perhaps the most important one, is Professor Jones calling attention to the roles of individual entrepreneurs and firms in the globalization of the world economy. These entrepreneurs and firms have unambiguously demonstrated their almost boundless wealth-creating capabilities but have also contributed, perhaps unintentionally, to considerable wealth disparities (da Silva Lopes, Casson, \& Jones, 2019; Jones, 2013).

\section{The Long Haul}

Drawing sustained attention to the relevance of a historical (longitudinal) perspective in any academic and societal setting requires vigilance, intellectual flexibility and stamina. The publication and citation record of Geoffrey Jones since 1995 shows leaps and bounds in numbers of publications - some of these publications were obviously triggered by societal crises that demanded a historical perspective as Geoffrey Jones also explains in Chapter 2 of this volume.

Geoffrey Jones: Publications and citation records over time

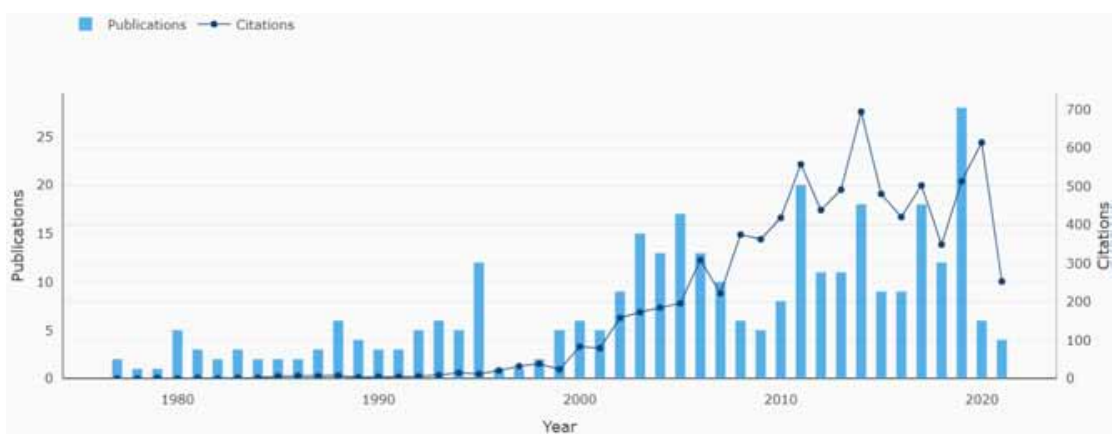

From the early publications in the 1980 s and 1990 s to the turn of the millennium, this has been a struggle for recognition. But since then, influenced by repeated crises and a wave of academic publications, his influence has become constant and growing. From 2007 onwards, not only publications surged, but also citations started to surpass a critical threshold of 200 per year. The financial crisis granted the study of business history extreme relevance. The following era of "globalization under threat" has continued to show the relevance of historical parallels, the importance of longitudinal studies and the importance of understanding the active role played by Multinational Enterprises in shaping the global economy.

Navigating the historical perspective in the IB discourse requires sustained and active attention. Geoffrey Jones has repeatedly reminded us of the relevance of a historical perspective. In 2006 (with Tarun Khnana), he pleaded to "bring 
history (back) into international business" (Jones \& Khanna, 2006). followed by an even stronger argument in 2020 in favor of the historical perspective as a fundamental precondition for the societal relevance of the IB profession (Jones, 2021). This volume can be interpreted as the next step in this effort. The contribution of Prof Jones and a number of his direct colleagues in Part I of this volume provides further evidence of the increased relevance of a longitudinal and historical take on IB.

\section{HISTORY MATTERS?}

\begin{tabular}{|l|l|}
\hline Then ..... & \\
\hline Fellow of Corpus Christi College & \\
\hline 1977: Cambridge - Newly elected Research & $\begin{array}{l}\text { 2018: Dubai - warning people about the danger } \\
\text { of de-globalization }\end{array}$ \\
\hline
\end{tabular}

\section{REFERENCES}

da Silva Lopes, T., Casson, M., \& Jones, G. (2019). Organizational innovation in the multinational enterprise: Internalization theory and business history. Journal of International Business Studies, 50(8), 1338-1358.

Jones, G. (2013). Entrepreneurship and multinationals. Northampton, MA: Edward Elgar Publishing.

Jones, G. (2017). Profits and sustainability: A history of green entrepreneurship. Oxford: Oxford University Press.

Jones, G. (2018). Varieties of green business: Industries, nations and time. Northampton, MA: Edward Elgar Publishing.

Jones, G. (2021). Renewing the relevance of IB: Can some history help? In A. Verbeke, R. van Tulder, E. L. Rose, \& Y. Wei (Eds.), The multiple dimensions of institutional complexity in international business research (pp. 77-92). Bingley: Emerald Publishing.

Jones, G., \& Comunale, R. (2019). Oral history and the business history of emerging markets. Enterprise \& Society, 20(1), 19-32.

Jones, G., \& Khanna, T. (2006). Bringing history (back) into international business. Journal of International Business Studies, 37(4), 453-468. 